\title{
Carbon monoxide Content of Exhaust Emissions from Agricultural Tractor Engines: A Case Study of Ogbomoso, Oyo State, Nigeria
}

\author{
AdewunmiTaiwo*1, Tawakalitu BolaOnifade ${ }^{2}$
}

${ }^{* 1}$ Department of Agricultural Engineering, LadokeAkintola University of Technology, PMB 4000,Ogbomoso, Oyo State,

Nigeria.

ataiwo@ lautech.edu.ng

${ }^{2}$ Department of Agricultural Engineering, LadokeAkintola University of Technology, PMB 4000, Ogbomoso, Oyo State, Nigeria.

\begin{abstract}
This study aims at contributing to the information buildup required for advocating the need for urgent reduction of environmental pollution by exhaust emissions from fossil fuel powered Engines in Nigeria. It was, concluded from the results obtained from the study that carbon monoxide content of the exhaust emissions of agricultural tractors are approximately forty nine(49) times higher than the recommended maximum level of $0.5 \%$ vol CO $(v / v)$ by the US Environmental Protection Agency (EPA). FIAT 70-666 contributed the largest content of 2.9 $\%$ vol of CO (v/v) while MASSEY FERGUSSON MF 375 contributed the least amount of $1.7 \%$ vol of $C O(v / v)$. Only the engine capacity had significant effect on the carbon monoxide content of the exhaust emissions of the agricultural tractors; the model/make selection did not significantly affect the $\mathrm{CO}$ content of their exhaust emissions.
\end{abstract}

Keywords-Carbon monoxide, Exhaust emissions, diesel engines, air pollution, agricultural tractors.

\section{INTRODUCTION}

Air-pollution is basically the presence of foreign substances in air in excessive concentration which adversely affects the well-being of man, animal as well as their surroundings. Whenever the delicate balance among the air components is upset, air is said to be polluted. Apart from natural air pollution phenomenon such as volcanic eruption, increased human activities producing harmful gases from motor vehicles, aircrafts, vessels and power stations, etc have been implicated for the sudden upsurge in air-pollution within the past few decades (EPA, 2014).According to EPA, (2012), air-pollution is a significant risk factor for a number of health conditions including respiratory infections, heart disease, and stroke and lung cancer. Children below the age of five years living in developing countries have been identified as the most vulnerable population in terms of total deaths attributable to air-pollution (WHO, 2008).

The introduction of fossil fuel burning auto motives into our modern lifestyle has had a huge impact on our environment, albeit our health conditions.So serious is this that fossil fuel combustion, especially as it occurs in auto motives, has been identified as the largest contributor to air-pollution in the world (Walling, 2014). A smoky automotive is that which emits visible smoke from its exhaust pipe for a continuous period of more than 10 seconds. In other words an automotive is not classified as smoky if its visible exhaust emissions consists of condensed water vapour which are often seen when the engine has just been started, particularly on cold days (Taysavang, 2014).

The so called smoke is actually an agglomeration of solid particles which are by-product of incomplete combustion which can significantly increase the quantity of certain toxic chemicals discharged by auto motives into the atmosphere (Yao, et al., (2011). These chemicals can cause mild to severe irritation to the eyes, nose, throat and lungs. Some of them can also be absorbed directly into the body through the skin causing immediate deterioration in general health condition. The extent of these detrimental effects on human health is related to the length of time for which an individual is exposed to automotive emissions, the concentration of the toxic chemicals in the fumes breathed and numerous other factors such as age and health (EPA, 2012).

Approximately 5 to $10 \%$ of the exhaust gases from an average automobile or truck engine constitutes carbon monoxide. The amount produced by different engines and at different times by the same engine varies considerably. Generally, it tends to be less whenever the engine is 
operating efficiently (Wjst, et al., 1993).A substantial proportion of diesel engine emissions causing environmental problems are produced by heavy duty work machinery such as agricultural tractors, forestry and construction machines (Hansson et al., 2001). The Exhaust emissions from these machines have serious negative impacts on human health and the environment. In order to reduce these emissions, experts in environmental protection organizations have developed and introduced standards which are being tightened continuously (Larson and Hansson, 2011). Unfortunately most of these standards are often concerned with existing vehicles despite the fact that vehicles older than 10 years are mostly responsible for 25 $40 \%$ of all exhaust emissions from off-road machines (Beaton, et al., 1995).

Carbon monoxide which is a colourless, odourless and poisonous gas that can be further burned to form carbon monoxide $(\mathrm{CO} 2)$ is produced in any combustion process whenever there is a deficiency of oxygen. In most fossil fuel burning automotive engines, some of the fuel will not go through complete combustion process get burned whenever there is a deficiency of oxygen in oxygen supplied to the combustion chamber. These unburned fuel end up as pollutants in the exhaust fumes discharged from the engines (Qamar, 2008). Exposures at the rate of 100 parts per million ( $\mathrm{ppm}$ ) or greater could be very dangerous to human health if not fatal (Prockop and Chichkova, 2007). Causes of excessive carbon monoxide production in automotives include, but not limited to, leaky injectors, high fuel pressure, improper closed loop control, dirty air filter, etc.It is a chemical asphyxiant because it prevents sufficient oxygen from reaching the tissues of the body-a condition which can cause death quickly (HEI, 1995).Under this condition, it combines permanently with the haemoglobin in the bloodstream causing a decrease in the amount of oxygen that can be delivered to the tissues during respiration thus resulting in dizziness, loss of consciousness and, in some cases, outright death (Wjst et.al, 1993). The affinity between haemoglobin and carbon monoxide is approximately 230 times stronger than the affinity between haemoglobin and oxygen so haemoglobin easily binds to carbon monoxide in preference to oxygen (Bateman, 2003).

The aim of this study was to contribute to the information buildup required for advocating the need for urgent reduction of environmental pollution by exhaust emissions from fossil fuel powered Engines in Nigeria. The specific objectives were to: (1) determine whether or not the carbon monoxide content of the exhaust emissions of the sampled tractors were higher than the maximum level recommended by the Environmental Protection Agency (EPA), (2) determine which make and model in the sampled tractors had the highest and lowest carbon monoxide content in its exhaust emissions (3) determine whether or not the engine capacities and model selection significantly affected the carbon monoxide content of exhaust emissions of sampled agricultural tractor engines.

\section{MATERIALS AND METHODS}

The study area, Ogbomoso is located in Southwestern Nigeria between latitude $8^{\circ} 06^{\prime} 70^{\prime \prime} \mathrm{N}$ and $8^{\circ} 06^{\prime} 98.7^{\prime \prime} \mathrm{N}$ and between longitude $4^{\circ} 14^{\prime} 28.2^{\prime \prime} \mathrm{E}$ and $4^{\circ} 14^{\prime} 56.9^{\prime \prime} \mathrm{E}$. Although Ogbomoso consists of five local government areas, the metropolis consists of only two (Ogbomoso North and Ogbomoso South local government areas). It is also a major transit point between the South Western and Northern States of Nigeria; this makes untold number of heavy duty road transport tractors attached to loaded trailers to pass through the metropolis on daily basis. This makes the entire area vulnerable to air pollution as a result of the exhaust fumes of these vehicles.

In this study, twenty (20) agricultural tractors operating around and within Ogbomoso metropolis were randomly selected for exhaust emission test with the use of a Model G1424 GunsonGastester which is a Digital Exhaust Carbon monoxide Analyzer with Pulse Pump. The Gastester is an exhaust gas analyzer that works on the "Hot Wire" or "Thermal Conductivity" principle. According to this principle, the thermal conductivity of exhaust gas varies in proportion to the amount of carbon monoxide present. The display is calibrated in volume percent carbon monoxide (CO \%). It is equipped with a calibration control which is used to set the reading of the display to show $2.0 \%$ at the start of the tests, before the probe is inserted into the exhaust pipe. This calibrated position represents what the instrument would register when the probe is in the air; it is coincidental that air should measure the same as exhaust gas with $2 \% \mathrm{CO}$. When the probe is subsequently inserted into the exhaust pipe, the display of the instrument may increase or fall from the calibrated condition. Two core cables with alligator clips are provided for connecting the gas tester to the $12 \mathrm{~V}$ car battery. The exhaust probe is a metal pipe which was inserted into the exhaust pipe and retained in position by the metal springs which pressed against the interior wall of the exhaust pipe. When in use, the transparent rubber pipe connected to the exhaust probe was made to slope down continuously to the Pulse Pump/Water Trap so that water that may run down could be automatically expelled from the drain pipe. 
The 20 agricultural tractors consist of 2 makes and 3 models (Massey Fergusson MF 375, FIAT 666 and FIAT 70-666). The engine of the tractors were run and allowed to be thoroughly warm before the tests began. It was not enough to leave the tractors warm while they were parked; they were taken out for a drive and the tests did not commence until water temperature, exhaust system and engine were running at normal operating temperature. In addition to making sure that the tractor engines were thoroughly warm, they were parked in a convenient position in the open air, with the handbrake applied. Extra care were taken to make sure that the instrument was never placed directly in the exhaust stream because the reference cell required clean air for accurate readings.

In order to obtain uniform database of warmed up tractors, data were collected from tractors entering the tractor stations and that have been running for at least 10-15 minutes in both the two local government areas visited in Ogbomoso metropolis because vehicles with cold engines emit much higher CO levels(Jaffe and Herndon, 1995). It was here that carefully designed questionnaires with appropriate questions were distributed among each of the drivers selected for the survey as survey instruments.

The questionnaires were later collected and decoded after which relevant engine parameters consisting of engine capacity and tractor makes and models were compiled and used to carry out analysis of variance in a Completely Randomized Design Experiment with the results presented as shown in Tables 1 and 2 .

\section{RESULTS AND DISCUSSION}

The average carbon monoxide content of the exhaust emissions of the sampled agricultural tractors in this study is $2.445 \%$ vol of $\mathrm{CO}(\mathrm{v} / \mathrm{v})$ with FIAT 70-666 contributing the largest content of $2.9 \%$ vol of $\mathrm{CO}(\mathrm{v} / \mathrm{v})$ while MASSEY FERGUSSON MF 375 contributed the least amount of $1.7 \%$ vol of CO (v/v).

The average was 49 times higher than the maximum level recommended by the World Health Organization (WHO) and US Environmental Protection Agency (EPA).

Effect of Engine Capacity on Carbon monoxide Content of Exhaust Emissions from the Tractors Studied

The results in the ANOVA table in Table 1, shows that the capacity of the diesel engines installed on the Agricultural tractors did not significantly affect the carbon monoxide content of their exhaust emissions. This implies that bringing high capacity tractors to Ogbomoso albeit, Nigeria, in large numbers is not going to have any deleterious effect on the heath of the populace. This is good news for the potential agricultural production system of the country as higher capacity implies higher power input which, in turn, implies higher yield and subsequently higher income for the farmers.

Table.1: ANOVA Table for the Carbon monoxide Content of Exhaust Emissions from Two Different Engine Capacities of Twenty Agricultural Tractors Operating within Ogbomoso and Environs, \% Vol of CO (v/v)

\begin{tabular}{|c|c|c|c|c|c|}
\hline \multirow{2}{*}{$\begin{array}{l}\text { Source } \\
\text { of } \\
\text { variation }\end{array}$} & \multirow[t]{2}{*}{ d.f. } & \multirow{2}{*}{$\begin{array}{l}\text { Sum of } \\
\text { squares }\end{array}$} & \multirow{2}{*}{$\begin{array}{l}\text { Mean } \\
\text { square }\end{array}$} & \multirow[t]{2}{*}{$\mathbf{F}$} & $\mathbf{F}_{\text {critical }}$ \\
\hline & & & & & $F_{0.05}(1,18)$ \\
\hline $\begin{array}{l}\text { Engine } \\
\text { capacity }\end{array}$ & 1 & 0.69 & 0.69 & 4.31 & 4.41 \\
\hline Error & 18 & 2.08 & 0.16 & & \\
\hline Total & 19 & 2.77 & & & \\
\hline
\end{tabular}

Effect of Model Selection on Carbon monoxide Content of Exhaust Emissions from the Tractors Studied

The results in the ANOVA table in Table 2 shows that the level of carbon monoxide content of the exhaust emissions from the diesel engines installed on the tractors in this study was significantly affected by their model selection.

This result implies that bringing tractors into Nigeria without paying attention to the models brought in by the authorities concerned portends a great danger to the health of not only the farmers but the entirely populace in the country. A remarkable amount of effort should be made by governments at various level in the country to emphasize the need for carrying out rigorous tests on each tractor model brought into the country with a view to issue out clearance certificate by the environmental protection agency.

Table.2: ANOVA Table for the Carbon monoxide Content of Exhaust Emissions from Three Different Models of Twenty

Agricultural Tractors Operating within Ogbomoso and Environs, \% Vol of $\mathrm{CO}(\mathrm{v} / \mathrm{v})$

\begin{tabular}{|l|l|l|l|l|l|}
\hline $\begin{array}{l}\text { Source } \\
\text { of } \\
\text { variation }\end{array}$ & d.f. & $\begin{array}{l}\text { Sum of } \\
\text { squares }\end{array}$ & $\begin{array}{l}\text { Mean } \\
\text { square }\end{array}$ & F & $\mathbf{F}_{\text {critical }}$ \\
\cline { 3 - 6 } \\
$\begin{array}{l}\text { Tractor } \\
\text { models }\end{array}$ & 2 & 0.8775 & 0.43875 & 3.96 & 3.59 \\
\hline Error & 17 & 1.882 & 0.11071 & & \\
\hline Total & 19 & & & & \\
\hline
\end{tabular}

\section{CONCLUSIONS}

The carbon monoxide content of the exhaust emissions of some agricultural tractors imported into Nigeria were 
studied under using Ogbomoso as a case study and the following major conclusions were drawn:

1. The carbon monoxide content of the sample tractors were higher than the maximum recommended level by the by both the Environmental Protection Agency (EPA) and the World Health Organization (WHO).

2. Fiat 666 had the largest carbon monoxide content in its exhaust fume out of the makes and models of sampled agricultural tractors.

3. While the engine capacity of the agricultural tractors did not have any significant effect on the carbon monoxide content of their exhaust emissions, the model selection significantly affected their exhaust emissions.

4. This result implies that bringing tractors into Nigeria without paying attention to the models brought in by the authorities concerned portends a great danger to the health of not only the farmers but the entirely populace in the country.

\section{ACKNOWLEDGEMENT}

The authors would like to express their sincere appreciation to the members of the Ogbomoso Tractor Owners Association for allowing them the use of their tractors for exhaust data collection. The cooperation of the chairman of the association, his tractor operators and, in fact, his entire team are immensely appreciated for the support and cooperation accorded our students, who played the role of research assistants, while carrying out the field experiments for this study.

\section{REFERENCES}

[1] Bateman, D.N. Carbon Monoxide. Medicine 31 (10): 233. http://dx.doi.org/10.1383\% 2Fmedc.31.10.41.27810. Accessed May7, 2014. 2003.

[2] Beaton, S.P., Bishop, G.A., Zhang, Y., Ashbaugh, L.L., Lawson, D.R., Stedman, D.H. On-Road Vehicle Emissions: Regulations, Costs, and Benefits. Science. 268 (1): 991-993. 1995.

[3] EPA. Carbon Monoxide: Chief Causes for Concern. United States Environmental Protection Agency. http://www.epa.gov/air/urbanair/co/chf1.html. Accessed March 2, 2014. 2014.

[4] EPA. Cars and Air Pollution. United States Environmental Protection Agency. www.epa.vic.gov.au/air/aq4kids/cars.asp. Accessed May 5 2014. 2012.
[5] Hansson, P.A., Lindgren, M., Nore, O. A. Comparison between Different Methods of calculating Average Engine Emissions for Agricultural Tractors, Journal of Agricultural Engineering Research. 80 (1): 37, 43. 2001.

[6] HEI. Diesel Exhaust: A Critical Analysis of Emissions, Exposure and Health Effects. Health Effects Institute. Cambridge, MA. 294pp. 1995.

[7] Jaffe, D. A., Herndon, S. Measuring carbon monoxide in auto exhaust by gas chromatography. Journal of Chemical Engineering. 72(1): 364-366. 1995.

[8] Larsson G., Hansson P.A. Environmental impact of catalytic converters and particle filters for agricultural tractors determined by life cycle assessment. Journal of Bio-systems engineering. 109: 15-21. 2011.

[9] Prockop, L.D., Chichkov, R.I. Carbon Monoxide Intoxication: An updated Review. Journal of the Neurological Sciences. 262 (1-2): 122-130. 2007.

[10] Qamar,A. Internal Combustion Engine Hand-out. http://engineersedge.weebly.com/uploads/4/6/8/0/4680 709/ice_handout2.doc. Accessed April 1, 2014. 2008.

[11] Taysavang, A. Humanity and Carbon Cycle. https://prezi.com/eeymkrndw2jy/humanity-and-thecarbon-cycle/. Accessed February 3, 2014. 2014.

[12] Walling, A. Car Exhaust Pollution. https://prezi.com/lnjbmhdbxqar/car-exhaust-pollution/. Accessed January 9, 2015. 2014.

[13] WHO. Air Quality and Health. WHO Fact Sheet No. 313. World Health Organization. Geneva, Switzerland. http://www.who.int/mediacentre/factsheets/fs 313/en/in dex.html) Accessed April 18, 2014. 2008.

[14] Wjst, M., Reitmeir, P., Dold, S., Wulff, A., Nicolai, T., Loeffelholz-Colberg, E.F., Mutius, E. Road Traffic and Adverse Effects on Respiratory Health in Children.

1993. http://www.bmj.com/content/307/6904/596.abstract. Accessed April 18, 2014.

[15] Yao, Z., Huo, H., Zhang, Q., Streets, D.G., He, K. Gaseous and Particulate Emissions from Rural Vehicles in China. Atmospheric Environment. 45: 3055-3061. 2011. 